\title{
ENVIRONMENTAL MANAGEMENT APPROACHES AND WATER RESOURCES IN THE STRESSED REGION OF THRIASSION, GREECE
}

\section{C.A. KARAVITIS 1 ,* \\ A. BOSDOGIANNI ${ }^{2}$ E.C. VLACHOS 3}

Received: $31 / 12 / 00$

Accepted: 05/10/01

\author{
1, * Water Resources Planning and Management \\ Civil Eng. Dep., Colorado State University \\ Fort Collins, CO 80523 \\ 2 Public Health Engineering \\ National Technical University of Athens, Greece \\ ${ }^{3}$ Dep. of Sociology and Civil Eng. \\ Colorado State University, Fort Collins CO 80523
}

* to whom all correspondence should be addressed e-mail: chrisk@hol.gr

\begin{abstract}
The present attempt has a two prong-emphasis. On the one hand it demarcates the physical, structural, social and economic parameters and the eliciting environmental problems in Thriassion Plain, the main industrial area of metropolitan Athens, Greece. On the other hand it attempts to delineate a framework of total unit management in terms of actions that may make possible the solution of long term pollution problems focusing on the whole spectrum of potential policy alternatives. Such an approach could contribute in presenting some options, for water resources management in particular and in general for natural resources management efforts, that may outline an environmental management framework necessary for a continuous, comprehensive and future oriented development of the area.
\end{abstract}

KEY WORDS: Environmental Management, environmental impacts, water resources, waste water, pollution, natural resources, wastes policies, Athens, Greece.

\section{INTRODUCTION}

The Thriassion plain is located west of Athens, in the Attica prefecture, approximately in the center of Greece (Figure 1). The region is separated from Athens only by a low mountainous chain and thus, the proximity of the Thriassion plain to the Athenian agglomeration made it a favorable site for industrial development and the corresponding economic activities. Starting ninety years ago, till today, the Plain has been woven into the greatest industrial concentration of Greece with, two major oil refineries, two steelworks, two of the biggest shipyards, cement factories, and quite a number of chemical, mechanical, transportation, tire and plastic industries. In addition, existing great ancient monuments in the area (city of Eleusis), the intensive agricultural activities of the past, haphazard urban and industrial development, and an altered natural environment are intensifying the environmental problems of 


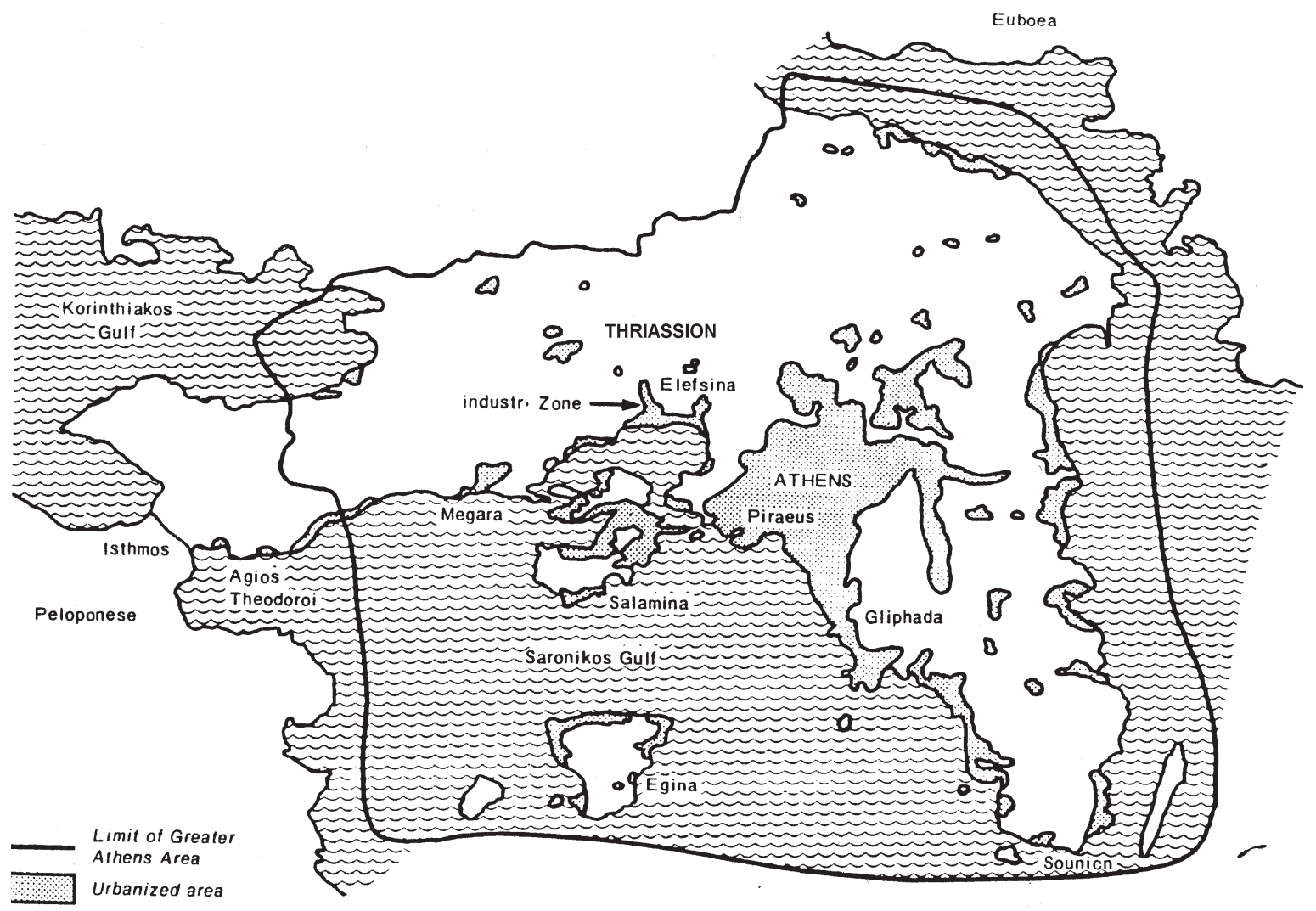

Figure 1. Metropolitan Athens Area and Thriassion Plain (adapted from O.E.C.D., 1983)

the Thriassion region. The plain is crossed by four major torrents, which are often flooding (with minimal flood control works), eliciting serious damages. On the same time they are used as open sewers for the industrial effluents, and hence are greatly polluted. The over-exploitation of the alluvial aquifer has led to sea-water intrusion extended for kilometers away from the coast. Overall the industrial by-products, and the absence of any serious waste treatment efforts as well as of timely and organized ad-hoc policies, has polluted to a great degree the water resources, the land and the air of the Thriassion plain demarcating at same time the parameters of the problem at hand. In this regard, the emphasis in the following sections is on:

1. Presenting the data and the parameters that delineate the Thriassion Plain as an extreme case of land, water and air pollution. At the same time underscoring the facts that the Plain is at the center of a heavily urbanized and historically significant region.

2. Showing the need for restoration and renova- tion, a framework of approaches and actions is described for comprehensive waste management, with a concentration in water resources and wastewater, based on a holistic environmental management framework, thus outlining relevant solutions integrating ecosystemic viability and the future of sustainable development.

Concluding, this research may point out the necessity of total unit management in terms of appropriate and reasonable actions that may make possible the solution of long term environmental problems leading towards the long term viability of the region.

\section{THE CONTEXT OF THRIASSION PLAIN}

The collection of material for the current effort about the Thriassion Plain took place between 1996 to 1999. The data have been collected through numerous visits in the area of interest in order to delineate as close as possible, the water and waste water infrastructure, as well as environmental, institutional and socio-economic condi- 
tions affecting the use and misuse of resources in the region. The data collection incorporated material from all environmental impact assessments submitted to the relevant authorities by the industries operating in Thriassion Plain. Such assessments were part of the regulatory permissions required in order to control the production of liquid and solid waste (total number 104). Personal communication with the pertinent authorities included the Eleusis Coast Guard, the Western Attica Prefecture directorships of Industry, City Planning and Public Health, the Ministry of Development, the Company of Water Supply and Wastewater of the Capital (EYDAP), the Municipalities and other local authorities. Finally, the existing law enforcement policies were analyzed and applied penalties for effluents standards violation were examined.

\section{Physiography and climate}

The Thriassion Plain is separated from the Athenian one by the Aigaleo hills to the east, while to the south opens to the bay of Eleusis (Figure 1). To the northwest a mountainous chain limits the plain. The region has an area of $345 \mathrm{~km}^{2}$ from which $20.6 \%$ is the cultivated land, $35.4 \%$ are pastures, $29 \%$ are forests and only $4.4 \%$ is the urban area. However the majority of the activities has been concentrated near the coastal area of the plain. This coastal part with an approximate area of $100 \mathrm{~km}^{2}$ includes the $25 \mathrm{~km}^{2}$ of the industrial section, the $15 \mathrm{~km}^{2}$ of the urban developments and the $12 \mathrm{~km}^{2}$ of the military airport.

One of the primary road axes of Greece, as well as primary railroad corridors of the country, is crossing the plain. The annual load is close to 30 million vehicles. Another problem of Thriassion is the absence of road infrastructure to support the industrial activities and thus heavy traffic has to cross a limited existing urban network. There are 13 harbor facilities on the coast with an average load of 5,500 ships per year. As a result from the $15 \mathrm{~km}$ of the Plain coastline the $12 \mathrm{~km}$ are used by the harbor and docking complexes. In addition $1 \mathrm{~km}^{2}$ of sea surface has been 'reclaimed' by the land due to the dumping of industrial solid waste.

The climate is characterized by hot dry summers and mild wet winters. According to the Meteorological Station in the Eleusis Airport (EYDAP, 1996) the average daily temperature varies from $9^{\circ} \mathrm{C}$ in January to $29^{\circ} \mathrm{C}$ in July and August. The winds are predominantly from the North $(30 \%)$ with an average between 2-4 of the Beaufort scale. The average annual rainfall is 390 $\mathrm{mm}$ (values from 1950-1992). It is expected a higher rainfall value for the upper part of the plain, nevertheless, there is no Meteorological station on the higher elevations to measure such differences. For the overall basin estimates are at about $420 \mathrm{~mm}$ of average annual precipitation (Antoniou et al., 1982). The rivers that cross the plain are ephemeral torrents, with only one small natural lake.

\section{Population and Industry}

The region is located only $20 \mathrm{~km}$ west of the Athenian conurbation, and thus it was early made a favorite site for industrial development. A map of the larger area has already been introduced in Figure 1. The first industry was established on 1875 , and by 1910 there were already 10 major units (cement, wine and liquors, olive oil refineries etc.). The first appearance for environmental pollution was recorded on 1930, due to the cement dust byproducts. However, in the decades of 1950 and 1960 the industrial growth was becoming almost exponential with the establishment of National importance industries, such as the Aspropyrgos Oil Refineries, the Petro-gas (synthetic fuel gases), Steelworks, Cement factories, Shipyards, chemical and plastic factories. In the following decades (1970's and 1980's) very few major industries were established, where as the existing ones were expanding their installations, attracting also satellite industrial activities. By the middle 1990's a decline in the number of industries was recorded. Currently according to the number of employees and the annual budget in relevant among them numbers, there are about 1000 small and medium size industries and about 15 large units, situated either dispersed or at eight industrial sites (2 at Eleusis, 5 at Aspropyrgos and 1 at Mandra). All this time uncontrolled and unauthorized dumping of industrial by-products, garbage and 'non-wanted' items, junkyards or automobile's 'cemeteries' and used tires yards have transformed the region to a 'waste sink' for the metropolitan Athens area. In this regard, the Thriassion plain became both an important and easily accessible area for the adjacent Athenian conurbation and a high risk environmental liability. 
Table 1: $\quad$ Population growth in Thriassion Plain (N.S.C., 1996; Company of Water Supply and Wastewater of the Capital, 1996).

\begin{tabular}{|l|r|r|r|r|r|r|r|}
\hline & \multicolumn{7}{|c|}{ Population } \\
\hline Municipality & $\mathbf{1 9 5 1}$ & $\mathbf{1 9 6 1}$ & $\mathbf{1 9 7 1}$ & $\mathbf{1 9 8 1}$ & $\mathbf{1 9 9 6}$ & $\mathbf{2 0 1 0}$ & $\mathbf{2 0 3 0}$ \\
\hline Eleusis (Elefsina) & 11,200 & 15,500 & 18,500 & 20,300 & 24,700 & 32,800 & 39,700 \\
\hline Aspropyrgos & 5,900 & 8,200 & 11,200 & 12,550 & 16,600 & 24,280 & 32,400 \\
\hline Mandra & 3,900 & 5,500 & 8,050 & 8,800 & 12,500 & 20,180 & 29,800 \\
\hline Magoula & 450 & 700 & 1,200 & 1,900 & 3,000 & 5,340 & 7,900 \\
\hline Total & $\mathbf{2 1 , 4 5 0}$ & $\mathbf{2 9 , 9 0 0}$ & $\mathbf{3 8 , 9 5 0}$ & $\mathbf{4 3 , 5 5 0}$ & $\mathbf{5 6 , 8 0 0}$ & $\mathbf{8 2 , 6 0 0}$ & $\mathbf{1 0 9 , 8 0 0}$ \\
\hline
\end{tabular}

Following the rapid industrial growth in the last 30-40 years, a parallel population increase has taken place. Table 1 presents the population growth in Thriassion Plain and the corresponding projections for the years 2010 and 2030. According to the 1991 census, the total population in the four major communities was 53,000 inhabitants and in 1996 the population has reached 56,800 inhabitants, in comparison to the 21,000 of 1951 . The rate of population increase has been declining in the decade of 1971/81 possibly due to the environmental degradation, however in the 1981/91 the establishment of new industries (particularly chemical) and the new job opportunities in a tough market, has led to a new rate increase despite the pollution problems. Nevertheless, the majority of the working force is still living in Greater Athens. Additionally, the changing land use from the traditional agricultural activities to the industrial developments, housing complexes etc. resulted to corresponding changes in the structure of the local economy and the accompanied shifting for the working force, from the agricultural sector to the industrial one. The agricultural activities were traditionally concentrated on olive groves, cereals and pistachios plantations. However the percentage of agricultural land use is continuously declining from the recorded $20 \%$. The reasons for such a trend may be mainly the shift towards industrialization, and secondary the limited irrigated area, the soil exhaustion, the unsuitable for the region corps, and the small size of the agricultural land properties. In this regard the value of agricultural land is ranging from $200 \mathrm{USD} \mathrm{m}^{-2}$ to $1000 \mathrm{USD} \mathrm{m}^{-2}$ with the higher ones closer to the industrial concentrations.

\section{Water resources}

The Thriassion watershed has a total area of 480 $\mathrm{km}^{2}$, an average annual surface runoff coefficient of 0.10 based on the average annual precipitation of $420 \mathrm{~mm}$. Thus the total annual volume of runoff is close to $20 \times 10^{6} \mathrm{~m}^{3}$ (Antoniou et al., 1982). The pertinent volume is drained through the following ephemeral streams (Figure 2):

- Sarantapotamos, with a watershed of $266 \mathrm{~km}^{2}$ is the largest torrent in the area. It is often flooded with serious damages. The latest flood of Jan. 1996 has cut-off the primary road and railroad arteries from Athens to Corinth.

- Saint George (Giannoulas) having a catchment of $110 \mathrm{~km}^{2}$. It is often flooded and it is also exhibiting major environmental problems since it receives a significant amount of effluents from the nearby industries.

- Soures, with a watershed of $50 \mathrm{~km}^{2}$. It is often flooded with serious damages on the western part of the plain.

- Saint John, which is having a $32 \mathrm{~km}^{2}$ watershed mostly in low elevation areas, with some flood problems in the past.

- The torrents of Maure Hora and Diylisteria are forming mainly on the lower plain with watersheds of $23 \mathrm{~km}^{2}$ and $12 \mathrm{~km}^{2}$ correspondingly.

Flood and floodplain protection works are missing except from a few minimal or inefficiently designed schemes in some of the torrents. The majority of the precipitation falls during the win- 


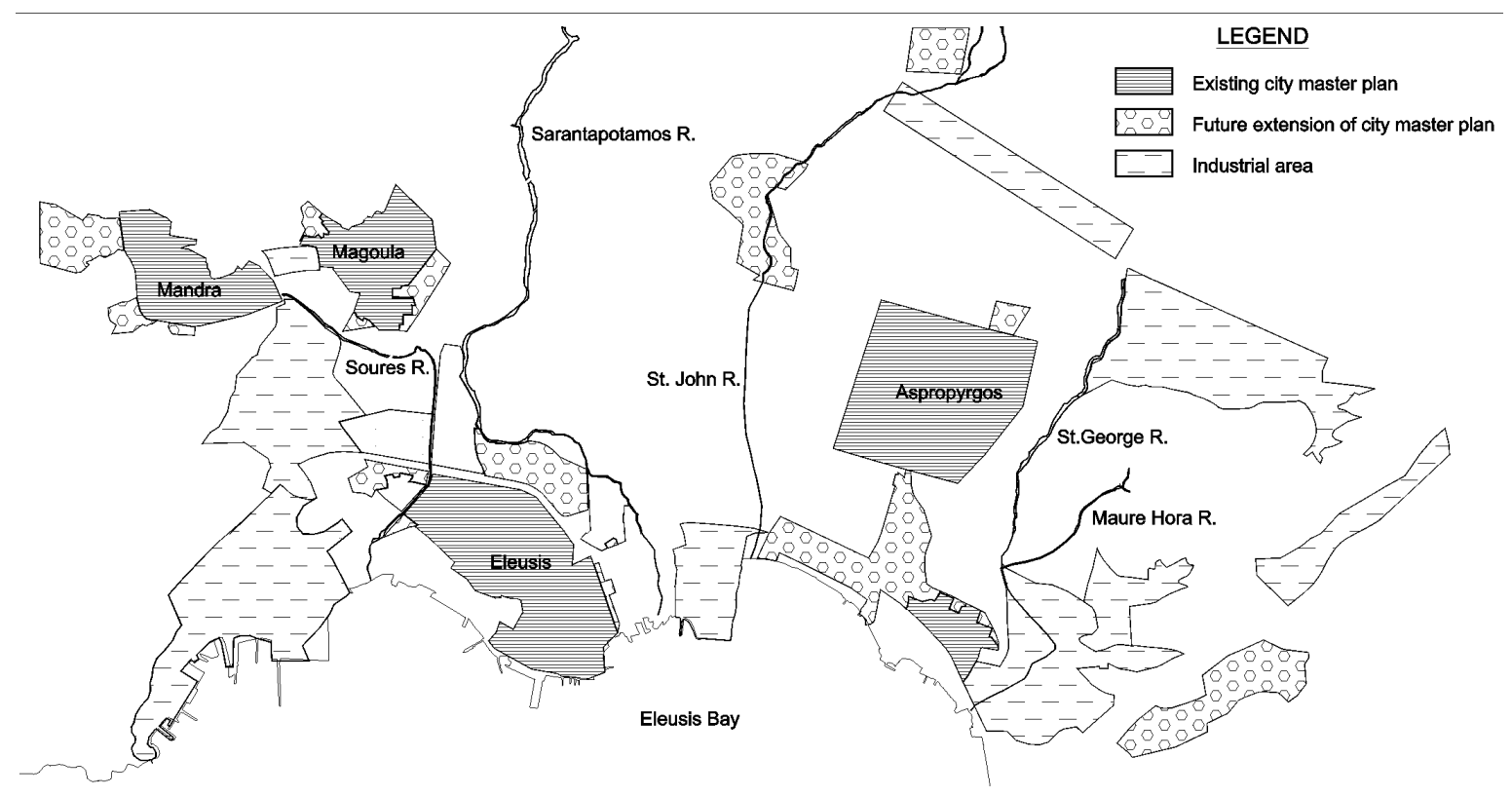

Figure 2. Main torrents in Thriassion Plain (adapted from EYDAP, 1996).

ter months creating also flush floods, whereas the summer period is extremely dry. Erosion problems are also present compounding to the flood impacts. As an indication, it is estimated that a medium range flood (50 $\mathrm{yr}$ return period) of the St. George torrent would cause damages close to 200 millions U.S.D. to the adjacent EL.D.A. oil refineries, apart from the other impacts (Karavitis, 1999b). On May 1999, plans for flood protection works were in the phase of final study. The plain had also two natural lakes, the Reiton lakes, an important part in the festivities of 'Eleusinian Mysteries' in ancient times. The smaller lake has been drained in 1950's, and now it is a part of the EL.D.A. oil refineries entrance area. The second lake survived, but it is seriously polluted by oil from the adjacent military unit and through infiltration from the EL.D.A. area. The overspill of the lake is drained to the sea compounding to the pollution problems.

Geologically, the higher elevations are limestones (mainly biosparudites) and dolomites of Triassiclower Jurassic age, interbeded with limestones of lower-middle Triassic. The plain consists of alluvial deposits, alluvial fans and older talus cones (Holocene age) and conglomerates. Limestones (biomicrudites, biosparudites and biomicrites) of Cenomanian Maestrichtian age are also present. Such geological formations exhibit low values of runoff coefficients and high infiltration rates to the underlining aquifers.

The main aquifers are forming in the plain conglomerates and limestones. The average annual withdrawals are close to $9 \times 10^{6} \mathrm{~m}^{3}$ and the annual rate of the ground water surface decline is about $0.25 \mathrm{~m}$. The depth of the groundwater surface is fluctuating from $30 \mathrm{~m}$ to $100 \mathrm{~m}$ and the withdrawal rate was recorded between $5-70 \mathrm{~m}^{3} \mathrm{~h}^{-1}$. It is estimated that more than 4000 wells and boreholes are concentrated in the coastal area of the plain (100 $\mathrm{km}^{2}$ area) with a $35 \%$ increase the last 22 years and used mainly for industrial purposes (Bosdogianni, 1997). The sea-water intrusion has reached a front 8-10 km away from the coast-line (Kounis, 1986). The groundwater has been also seriously polluted by heavy metals, nitrates and chloron. Agriculture and industry by dumping untreated their effluents, are mainly responsible for such a pollution. In addition, the unlined solid waste burial site for Metropolitan Athens to the east of the region (Nea Liossia-Aspropyrgos) with 1 million tn $\mathrm{yr}^{-1}$ of municipal wastes and 23,000 tn $\mathrm{yr}^{-1}$ of toxic wastes is another source of polluted leachates to the Thriassion Plain aquifers (Bosdogianni, 1997).

\section{Eleusis bay}

The major pollution sources for the Eleusis bay are the local industries, the wastewater of the 
Athens Metropolitan area of which $20 \%$ is entering the bay, by the eastern sound, and the ships, the shipping industry and related activities.

The Eleusis bay has an average depth of $18 \mathrm{~m}$, with a maximum one of $33 \mathrm{~m}$. The surface area of the bay is $67 \mathrm{~km}^{2}$ and its water volume $1.2 \times 10^{9} \mathrm{~m}^{3}$. The bay communicates with Saronicos gulf through Keratsini (Piraeus) sound to the east, and Megara sound to the west (Figure 1). Keratsini sound has a maximum depth of $12 \mathrm{~m}$ and a width of $1.2 \mathrm{~km}$ on the surface and $250 \mathrm{~m}$ in the bottom, whereas Megara sound has a depth of $8 \mathrm{~m}$ and a width of $600 \mathrm{~m}$ and $170 \mathrm{~m}$ correspondingly. The prevailing summer current is from east to the west with a rate of $450 \mathrm{~m}^{3} \mathrm{sec}^{-1}$. The average renewal time is $2-3$ months and the bay exhibits a high salinity concentration in the summer (Abatzoglou, 1987; Catsiki, 1991). Thus, the bay is extremely vulnerable to pollution.

The main pollution source of Elefsis bay is the industrial wastewater of the Greater Athens area, $20 \%$ of which was discharged until recently through the west opening to the bay and the seepage activities. The industry pollutes with both wastewater and solid wastes, which are gradually deposited to the sea-bottom. The Athenian wastewater carries dissolved and suspended material, which is also gradually deposited. Finally, the ship industry pollutes through oil products (ship-building, refueling, etc.), metallic by-products, paints and other chemicals as the second biggest Greek shipyard (one of the biggest in Europe) is located at the eastern part of Eleusis bay. Furthermore, there are one smaller shipyard and six ship demolishing units. The two shipyards

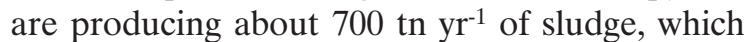
presumably are being dumped in the Athens landfill. The bay is also being used as a harbor for noncommissioned ships with a total number of about 450 vessels, almost double the area's capacity, thus creating another source of pollution. As a result, severe pollution and eutrophication are present in the bay, and the authorities have prohibited swimming and other recreational activities (Friligos, 1987). Pollution prevention measures were not being reported (Abatzoglou, 1987).

According to measurements made by the Pollution Control Center of Eleusis Municipality (EYDAP, 1996), covering the period 1984-1995, the turbidity at the center of the bay varying between $1.5-8 \mathrm{~m}$. The salinity appeared to be decreased near the offshore due to the discharge of the torrents. The prevailing pollutants are the nutrients due to municipal waste waters, $\mathrm{PO}_{4}-\mathrm{P}$ with concentrations varying between $3-18 \mathrm{mg} \mathrm{l}^{-1}$, $\mathrm{NO}_{2}-\mathrm{N}\left(0.07-6.20 \mathrm{mg} \mathrm{l}^{-1}\right), \mathrm{NO}_{3}-\mathrm{N}\left(0.20-2.20 \mathrm{mg} \mathrm{l}^{-1}\right)$ and $\mathrm{SiO}_{4}$-Si due to industrial waste and seepage activities. Furthermore the heavy metals as $\mathrm{Cu}, \mathrm{Cd}, \mathrm{Zn}, \mathrm{Pb}, \mathrm{Fe}, \mathrm{Cr}$, Ni with concentrations varying between 2-3.5 $\mu \mathrm{g} \mathrm{l}^{-1}, 1-2 \mu \mathrm{g} \mathrm{l}^{-1}, 10-80 \mu \mathrm{g} \mathrm{l}^{-1}$, 10-30 $\mu \mathrm{g} \mathrm{l}^{-1}, 1-40 \mu \mathrm{g} \mathrm{l}^{-1}, 2-20 \mu \mathrm{g} \mathrm{l}^{-1}, 1-13 \mu \mathrm{g} \mathrm{l}^{-1}$ approximately. DO concentrations deeper than $15 \mathrm{~m}$ were practical equal to zero during the summer months, due to stratification. Anoxic conditions prevail until November. A vertical thermal structure develops during March to October, though during the winter months a vertical water mixing and uniformity is noticed. DO concentrations varying between $4-14 \mathrm{mg} \mathrm{l}^{-1}$ throughout all the depth during November to March. However the water quality seems to be improved since 1985, as DO concentrations sustain at adequate level throughout all the year (Abatzoglou, 1987; Catsiki, 1991; EYDAP, 1996).

\section{WATER RESOURCES MANAGEMENT ISSUES Water resources management context and water supply}

In trying to outline measures for responding to the series of severe water quality problems in the Thriassion area it is important to understand the broader context Greek water resources management. The most pressing issue is the fact that there are many government departments dealing with water problems, but their activities are compartmentalized and not well-coordinated. Added to this is a water law system which is not responsive to modern issues of an industrial society and widely scattered, thus permitting overlapping functions, multiple advisory bodies and insufficiently decentralized management responsibilities through regional organizations. The law tends to be also deficient in the case of pollution issues, where quality standards for water bodies and/or effluent have not been clearly established. Furthermore, the sporadic consideration of water quality issues in a coherent water policy and the absence of systematic, uniform and enforceable pollution charges have compounded problems and have handicapped the water resources management efforts (Dalacu, 1998). 
The Attica sector, which includes Thriassion, is the only one of the 14 water sectors in Greece where urban-industrial water consumption exceeds by far any other uses. The responsibility for the water supply and the wastewater of the Athens region belongs to the Company of Water Supply and Wastewater of the Capital (EYDAP). According to the existing legislation EYDAP is solely responsible for water supply and wastewater works to perform studies, construction, maintenance, repair, operation, financing, revenue, etc. However, for flood protection and pollution control works the Ministry of Environment, City Planning and Public Works (YPEXODE) has the responsibility of studies and construction, whereas EYDAP executes the remaining functions. The budget of EYDAP is supervised by the Ministry of Economics (Karavitis, 1999a). Thus, the unsystematic and duplicating efforts for coordinated water and water infrastructure management.

The haphazard urban development in the recent decades has been compounded by an almost total absence of city planning, by the serious environmental deterioration resulting from industries build in the sea front or even inside the archaeological sites (ancient theatre and stadium). In this context, the water supply system had to follow already existing routes with the corresponding problems and losses up to $30 \%$ (Karavitis, 1999a). The urban water consumption, including losses in the water supply system, was about $12.5 \times 10^{6} \mathrm{~m}^{3}$ in 1995 provided by EYDAP. In the same year, the per capita consumption was estimated at $170 \mathrm{l} \mathrm{inh}^{-1}$ day $^{-1}$ without losses. It is forecasted that by 2030 the per capita consumption would reach $235 \mathrm{l} \mathrm{inh}^{-1}$ day $^{-1}$ (EYDAP, 1996). The industrial water consumption cannot be safely estimated, since the industries are consuming mainly groundwater and sea water mostly for the cooling process. Indirectly, it may be derived, that the industrial water consumption from the pertinent sources would be at the range of $50 \times 10^{6} \mathrm{~m}^{3} \mathrm{yr}^{-1}$ taking into account the total amount of effluents.

\section{Wastewater issues}

In Thriassion, as well as in the whole country, wastewater and wastewater systems have been treated incrementally without the requisite comprehensive planning. Currently, the region is lacking both a wastewater and a stormwater collection system. The urban area is being serviced by septic tanks, which are polluting the aquifers through seepage and by over spilling to the surface. Plans for the construction of stormwater and wastewater systems are in the phase of final design studies. The urban wastewater load was $8,200 \mathrm{~m}^{3}$ day $^{-1}$ in 1996 and it was estimated to reach $22,000 \mathrm{~m}^{3}$ day $^{-1}$ by 2030 . For the industrial wastewater in 1985 , a daily volume of $141,000 \mathrm{~m}^{3}$ (including cooling water) was damped untreated in Thriassion plain and Eleusis bay, with a load of 1.7 tn $\mathrm{BOD}_{5}$ day $^{-1}, 1.3$ tn $\mathrm{N}_{\text {day }}{ }^{-1}, 0.09$ tn $\mathrm{P}_{\text {day }}{ }^{-1}$

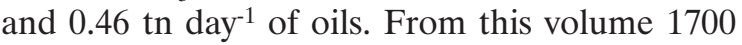
$\mathrm{m}^{3}$ day $^{-1}$ were arriving in the bay through Saint George torrent. In 1996, the daily hydraulic load of only the four major industries was about $125,000 \mathrm{~m}^{3}$ day $^{-1}$, whereas that one of the approximately remaining 100 industries has been estimated at around $2900 \mathrm{~m}^{3}$ day $^{-1}$ (Abatzoglou, 1987; Stamatiadis, 1993).

\section{LONG-RANGE EVALUATION OF ENVIRONMENTAL MANAGEMENT APPROACHES IN THRIASSION PLAIN Sustainable Environmental Management Interfaces in Thriassion Plain}

All the previous sections have emphasized the centrality and far-reaching consequences of waste in modern life as well as in the case of an industrialized region such as the Thriassion Plain. The historical data all over the planet have pointed out to vast amounts of waste generated and to discrepancies between their generation and disposal. The key challenge in all localities is that while indiscriminate disposal may be a comparatively inconsequential problem when the pollution and industrial production are small, it becomes a different story for industrial production characterizing megalopolitan and industrialized concentrations in many countries.

Thus, waste disposal has been elevated today into a major problem and part of a broader environmental pollution challenge. The last twenty years have not only increased the visibility of waste but have also produced demands for more complex socio-economic responses to what used to be considered a simple technological challenge. The environmental, economic and sociological dimensions of the problem and long range-emphasis have thus become central considerations. 
In this regard, there are basically four options available to control pollution resulting from the generation of wastes (Vlachos, 1992):

1. improve the assimilative capacity of the environment;

2. change time and place of discharges in order to take advantage of locations with better assimilative capacity;

3. change the form of waste residuals;

4. reduce the total volume of waste discharges.

At the same time there are three basic strategies for dealing with waste and, developing a more integrated waste management policy (Grigg, 1986). For solid waste, by far, the most common and cheapest disposal mechanism is the sanitary landfill (secondary are the incineration systems). However, the use of sanitary landfill systems will continue to depend on suitable space, transportation costs, environmental consequences and public acceptance. For wastewater, a wastewater collection system and a treatment plant are the principal tools of wastewater disposal and management. The third and complimentary alternative for waste disposal is recycling. The advantages for such an approach are not only the obvious economic benefits but also the ultimate significant reduction in materials flow, the conservation of resources for future use and the attendant environmental benefits. Yet, these three strategic alternatives for waste disposal are not independent of each other. For example, increases in recycling help reduce volumes of material going to landfills and to wastewater systems. However, landfills and wastewater treatment systems remain also the most acceptable disposal method for the Thriassion Plain. But here is the next challenge: what is apparent necessity engenders the biggest controversy, especially because of public perception.

Behind all these remarks as to waste and social responses lie the facts of the increasing stream of waste as a result of technology, affluence, population and shifting cultural values. Thriassion Plain and the whole Attica region have become part of a vast megalopolitan expansion due to historical conditions, lack of coherent planning, and the exigencies of political compromises. The dramatic recent growth of Greater Athens and the urban sprawl in Attica intensify many problems inherent in the environmental and economic structure of the region. All relevant data point out to the tremendous centrifugal movement from the cen- ter and the suburban expansion with a $24.5 \%$ increase rate throughout the Attica plain (Karavitis, 1999a). More important, since the 1980s due to both European Union developments as well as local concerns, environmental considerations become central in the life of the region and part of efforts for accounting for long-range impacts and consequences.

The challenge of waste disposal (in all forms and sources) of the Thriassion region is parallel to the waste disposal in many parts of the planet. Beginning from groundwater pollution and noise pollution it may be particularly emphasized the aesthetical or visual pollution associated with waste and with the larger problems of public health and ecological vulnerability of the region. In this regard, the Thriassion Plain offers a unique opportunity in studying water resources and environmental management as a succinct case of haphazard development, resources overexpoitation and serious pollution problems. The area provides an unusual combination of unfavorable conditions such as:

- absence of infrastructure;

- lack of historical knowledge of the waste stream or budget;

- lack of institutional support and mobilization;

- non-involvement of the public;

- absence of planning and capital investments;

- overexploitation of water resources in a region of limited resilience;

- lack of environmental consciousness in a fragile environment.

Hence, the challenge of resources, and effluent control, in the Triassion Plain may be formulated by considering some broader questions, namely key policies that outline the problem of waste as part of a comprehensive, systemic long-range strategy of waste management.

\section{Towards holistic waste management}

The most pressing issue in Thriassion Plain regarding wastewater problems is the immediate design, construction and operation of a wastewater collection system for the municipalities and the industrial sector, as well as the corresponding wastewater treatment plant. Such projects are already under way by the authorities. Provision is made for the construction of the sewerage system and the Waste Water Treatment Plant (WWTP), which will serve the urban, rural and the industrial areas of 
Table 2. Estimated mean waste water flows in Triassion Plain $\left(\mathrm{m}^{3} \mathrm{~d}^{-1}\right)$

\begin{tabular}{|l|r|r|r|}
\hline Wastes & $\mathbf{1 9 9 6}$ & $\mathbf{2 0 1 0}$ & $\mathbf{2 0 3 0}$ \\
\hline Municipal wastes & 8,200 & 14,000 & 22,000 \\
\hline Industrial wastes & 2,300 & 4,400 & 12,500 \\
\hline Special wastes (one hospital and two military camps) & 700 & 2,400 & 2,500 \\
\hline Infiltration & 3,100 & 4,200 & 5,000 \\
\hline Total & $\mathbf{1 4 , 3 0 0}$ & $\mathbf{2 5 , 0 0 0}$ & $\mathbf{4 2 , 0 0 0}$ \\
\hline
\end{tabular}

Thriassion Plain. The design of the treatment and sewage system is briefly outlined below.

To start with, the liquid industrial waste characterised as toxic, explosive, flammable or caustic materials, as well as those containing substances which might inherent the biological activity (acids, non ferrous metals, oils, pesticides) would not be accepted to the sewerage system or to the WWTP. Another restrictive design parameter would be the higher investment cost due to the increased volume of wastes. Hence the liquid wastes from the two main petroleum refineries of the area, the lubase regeneration and the blowing asphalt plants, the metal plating, the accumulators, the paint and agrochemical industries and the tanneries would not be connected to the sewerage system. All the pertinent industries should take the necessary measures to achieve maximum possible reduction of hydraulic and pollution loads at the source with the conversion of the process technology or without such a procedure (cooling water recycling, material reuse, metal recovery, evaporation of bath water), as well as by pretreating their waste water. After the inplant pre-treatment, further treatment of toxic liquid wastes and sludge is planned to take place in the central treatment plant for toxic wastes, which would be a common one for the Attica and Boiotia Prefectures. The present toxic load is estimated at $600 \mathrm{~m}^{3}$ day $^{-1}$. However, these plans have not yet been realised as even the decision about the location of the pertinent plant is still pending (May, 1999).

Paper, dye-finishing, the olive oil and the food industries by-products would be connected to the sewerage and treatment system after pre-treatment, in order to reduce the pollution loads and comply with the effluent standards set by the Prefectural Decision (1979). Currently, such wastes are estimated at about $2,300 \mathrm{~m}^{3} \mathrm{~d}^{-1}$.

The estimated mean wastewater flows and the corresponding projections for the years 2010 and 2030 in $\mathrm{m}^{3} \mathrm{~d}^{-1}$ that would be treated in the plant are presented in Table 2 .

The Eleusis Bay will receive the treated effluents from the WWTP through a submerged conduit. This bay is characterised as highly eutrophic. Hence it is recommended to be considered as a sensitive receiving body according to the EE Directive 91/271, which sets minimum standards for disposal of sewage to sensitive areas. As a consequence and in order to comply with the terms of the above mention Directive on the treatment of the waste water, the treated effluent quality should be: $B_{5}=15 \mathrm{mg} \mathrm{l}^{-1}, C O D=100 \mathrm{mg} \mathrm{l}^{-1}$, $\mathrm{SS}=10 \mathrm{mg} \mathrm{l}^{-1}, \mathrm{TP}=1 \mathrm{mg} \mathrm{l}^{-1}, \mathrm{TN}=10 \mathrm{mg} \mathrm{l}^{-1}, 500-$ $1000 \mathrm{FC} 100 \mathrm{ml}^{-1}$. To achieve such a quality standard the waste water treatment plant should include the following units: pre-treatment (screening, sand removal), primary sedimentation, activated sludge, including nitrification-denitrification, chemical phosphorus removal, secondary sedimentation, polishing and UV disinfection as well as mechanical thickening, anaerobic digestion and dewatering of produced sewage sludge. Already such provisions have been incorporated to its design.

The management and disposal of the dewatered sludge, which is estimated to be $9,500 \mathrm{~m}^{3} \mathrm{y}^{-1}$ (year 2010) and 19,000 $\mathrm{m}^{3} \mathrm{y}^{-1}$ (year 2030), would be a part of the whole management of sewage sludge produced in Attica Prefecture. Namely if it would not contain heavy metals it should be disposed to the solid waste composting plant currently constructed at the boundaries of Thriassion Plain. In the case of high heavy metals concentration content, it should be disposed to the heat-drying unit 
Table 3. Evaluation of the context of Thriassion plain.

\begin{tabular}{|c|c|c|c|}
\hline $\begin{array}{l}\text { Resources and } \\
\text { Infrastructure }\end{array}$ & Data domain & $\begin{array}{l}\text { Organizational } \\
\text { framework }\end{array}$ & Policy \\
\hline $\begin{array}{l}\text { Limited and fragile } \\
\text { resources, } \\
\text { Topographic and city } \\
\text { planning limitations, } \\
\text { Haphazard and inef- } \\
\text { ficiently maintained } \\
\text { water infrastructure, } \\
\text { Lack of waste water } \\
\text { infrastructure. }\end{array}$ & $\begin{array}{l}\text { Abundance } \\
\text { of information, } \\
\text { Some collection } \\
\text { problems, } \\
\text { Lack of information } \\
\text { technologies } \\
\text { application in data } \\
\text { availability }\end{array}$ & $\begin{array}{l}\text { Lack of effective } \\
\text { coordination, } \\
\text { Lack of local } \\
\text { authorities } \\
\text { integration and } \\
\text { public participation, } \\
\text { Partial responses, } \\
\text { Fragmentation of } \\
\text { water and waste } \\
\text { water management }\end{array}$ & $\begin{array}{l}\text { Lack of effective sys- } \\
\text { tems of monitoring } \\
\text { and evaluation, } \\
\text { Centralized decision } \\
\text { making, } \\
\text { lagging enforcement, } \\
\text { Crisis management } \\
\text { (floods, pollution } \\
\text { control) } \\
\text { Tendency towards } \\
\text { technical solutions }\end{array}$ \\
\hline
\end{tabular}

of the dewatered sludge at Psyttalia island Waste Water Treatment Plant serving the Metropolitan Athens area, following the final disposal of dry sludge as fuel.

The treated effluent volume which is estimated to be $25,000 \mathrm{~m}^{3} \mathrm{~d}^{-1}$ (year 2010) should be used for agricultural and landscape irrigation. Another major use of reclaimed municipal wastewater should be in the high water consumption industries of Thriassion Plain, primarily as cooling water or at the process needs. These industries apart from the large sea water volume consumed at open circuits, they also use $14,000 \mathrm{~m}^{3} \mathrm{~d}^{-1}$ ground water as well as $5,000 \mathrm{~m}^{3} \mathrm{~d}^{-1}$ potable water. The replacement of the ground water volume by the reclaimed water would be of primary importance. In this regard, the over-exploited aquifers should start to recover. However, a comprehensive waste management approach should include some additional elements, apart from the pertinent obvious engineering ones. In this context, encompassing the specific technical steps are the following supplementary cultural and economic approaches such as:

- systems of monitoring and evaluation

- cultural awareness of the larger problem of waste production and disposal;

- the social structure and institutions that tend to be conducive to comprehensive management;

- the appropriate legal mechanisms and regulatory frameworks;

- citizen mobilization in terms of awareness and public participation;
- proper training and "environmental" education as to society's discards;

- financial incentives, especially for treatment recycling and reuse; and,

- grassroots and community initiatives for innovative schemes of confronting the problem of waste.

- emphasize the culture of sustainability and the dilemma that affluence leads to effluents.

Based on the previous discussion, the context of Thriassion Plain with regard to a more comprehensive evaluation should be a more complex interaction of the categories of elements outlined in Table 3.

In an effort to summarize the above list of concerns, conflicts and crises linking sustainable development and integrated environmental management the following interacting issues may be demarcated in relation also to some more extensive comments on such crises made by Vlachos and Braga (2001):

- A water supply and demand crisis that represents a predominantly engineering dimension. Management and pollution control issues should be included such as the promotion of more desirable levels and patterns of use of the resources; augmenting fresh water supplies through e.g. conservation, reuse, conjunctive water use, etc.

- A deteriorating environmental quality crisis that can be translated into an ecological dimension of urban pollution problems. A variety of health issues may be encounter, poor water, air 
and soil quality, lack of adequate sanitation qualities, soil and groundwater contamination, as well as interference of resources development systems with the proper functioning of natural life cycles.

- A data and information crisis, not only in terms of availability, validity, reliability or comparability but also as part of combining data and judgement, modelling, and the building of useful Decision Support Systems (Simonovic, 1996).

- An organisational crisis exemplified in a management dimension, such as the appropriate mix of competent personnel, facilities and procedures, as well as legal processes and administrative guidelines. In other words in capacity building and in managing a system effectively and efficiently using people who know what an urban water system is supposed to accomplish and understand how it functions.

\section{Policy Options}

All previous considerations have pointed out that in view of the problems in Thriassion Plain, it becomes important to emphasize broader strategies that could lead to long-term, integrated, and comprehensive environmental management approaches. Such approaches would confront the problem of an interchange among population, technology, industrial production practices, affluence and cultural attitudes and at the same time they could lead towards environmental sustainability and preservation. Expanding the remarks made by Uitto and Biswas (2000), also for industrial regions such the Thriassion Plain, it may be noted that:

- The lag between economic development and urban/industrial growth or the investment capacity for appropriate infrastructure. In other words of growth exceeding the capacity of national and local governments to plan and manage requisite services

- Unique spatial patterns of city and industry growth including the matching of resources and sanitation.

- Overall patterns of development and supply of water. In addition to water scarcity, there are excessive economic costs; the notion of water as a free good contrasted to commodity; extensive management problems and difficulties in institutional mobilisation; lack of national water pol- icy or an extended planning time horizon, etc.

- The increasing importance of environmental concerns and the emphasis on sustainability. Issues emerge regarding resources conservation, a shift from structural to non-structural solutions, new concerns with public health, and water-intensive production processes and its consequences. Furthermore, extensive environmental legislation and regulatory provision, including the recently adopted Water Framework Directive (WFD, 2000) in the European Union poses additional constraints. The WFD has far-reaching provisions for the protection of quantity and quality of surface and ground water, introduction of water pricing policies, integrated planning, and the strengthening of public participation. The common approach and objectives of the WFD emphasise not only quantitative and qualitative aspects of water resources, but contribute to the central concern of EU in ensuring sustainable water consumption and use.

- Exogenous factors such as climatic changes, globalisation, and new management principles, particularly with emphasis on non-hierarchical administrative focus and the quest for anticipatory, participatory integrated forms of organisational structures and managerial approaches. The above elements combined with the increased emphasis on sustainability, the response to the forces of social changes and the urgent need for integrated water management, imply first of all an alternative vision of the means by which ecologically sustainable and socially acceptable options may emerge (Butler and Maksimovic, 1999; Vlachos, 1997). Thus, given also increasing environmental awareness and the problems associated with a fragile environment, the obstacles to the implementation of a total environmental management program have been repeatedly emphasized as being not necessarily technological but predominantly economic and institutional (Vlachos and Braga, 2001). Thus practical, possible, immediate, economic and institutional solutions are needed to the problems of waste production and of excessive exploitation of irreplaceable natural resources. Then, based on the abovementioned considerations, the Thriassion Plain problem may involve the major objectives and policies presented in Table 4. The table contrasts existing or "real" management framework in Thriassion 
Table 4. Objectives and Policy Actions of long-range Waste Management in a holistic Environmental Management Approach. Comparison of "Ideal” to "Real” Policy Actions.

\begin{tabular}{|c|c|c|}
\hline \multirow{2}{*}{ OBJECTIVE } & \multicolumn{2}{|c|}{ POLICY ACTION } \\
\hline & IDEAL & REAL \\
\hline $\begin{array}{l}\text { Holistic } \\
\text { Management } \\
\text { Program }\end{array}$ & $\begin{array}{l}\text { - emphasis on holistic planning } \\
\text { - strict law enforcement } \\
\text { - application of long-range } \\
\text { planning }\end{array}$ & $\begin{array}{l}\text { - lagging law enforcement } \\
\text { - crisis management }\end{array}$ \\
\hline $\begin{array}{l}\text { Waste } \\
\text { Management } \\
\text { Technologies }\end{array}$ & $\begin{array}{l}\text { - } \text { recycling, reduction, reuse } \\
\text { - collection system and treatment } \\
\text { facilities } \\
\text { - prevent haphazard land disposal }\end{array}$ & $\begin{array}{l}\text { - minimal efforts for recycling, } \\
\text { reduction, reuse } \\
\text { - absence of collection system and } \\
\text { treatment facilities } \\
\text { - haphazard land disposal }\end{array}$ \\
\hline $\begin{array}{l}\text { Treatment } \\
\text { Systems }\end{array}$ & $\begin{array}{l}\text { - process analysis and design } \\
\text { - operation guidelines } \\
\text { - enforcement of treatment } \\
\text { standards }\end{array}$ & $\begin{array}{l}\text { Non-existing (in the phase of tender } \\
\text { process for construction) }\end{array}$ \\
\hline $\begin{array}{l}\text { Public } \\
\text { Participation }\end{array}$ & $\begin{array}{l}\text { - educate the public on all facets } \\
\text { of waste issues } \\
\text { - consult with the public } \\
\text { promote active participation } \\
\text { in planning and decision-making }\end{array}$ & Limited Public Participation efforts \\
\hline $\begin{array}{l}\text { Local Authorities/ } \\
\text { Institutional } \\
\text { Changes }\end{array}$ & $\begin{array}{l}\text { - promote local responsibility } \\
\text { - institutional incentives } \\
\text { - encourage innovative local } \\
\text { responses }\end{array}$ & $\begin{array}{l}\text { - just starting } \\
\text { - minimal institutional incentives }\end{array}$ \\
\hline $\begin{array}{l}\text { Industrial } \\
\text { Management } \\
\text { Systems }\end{array}$ & $\begin{array}{l}\text { - cooperative planning between } \\
\text { industry and local authorities } \\
\text { - treatment incentives } \\
\text { - equitable distribution of risks } \\
\text { - law enforcement/ violation } \\
\text { penalties }\end{array}$ & Lagging \\
\hline
\end{tabular}

Plain with a proposed "ideal" or more comprehensive management approaches. The "ideal" may also be considered as the new "paradigm" for changing circumstances in a complex, demanding and fast evolving social and economic environment. The comparison of the two categories may offer the derivation of environmentally oriented policy options and scenarios for the Thriassion Plain area or similarly affected areas.

By comparing the "ideal" with the real waste management situation, it may be deduced that the existing framework deviates from the ideal one.
Such a divergence may question the efficiency and effectiveness of the applied policy actions. Thus, the primary task of a holistic environmental policy would be to bridge the gap between the ideal and the real conditions. Policy options should concentrate on minimizing such a gap before it becomes chasmic through time. Such an effort should be based on reasonable policy actions emanating from and corresponding to the particular environment. The term reasonable should be interpreted as describing these actions that should consent in generating appropriate 
steps for effective environmental management, in the context of the area, according to a time framework. Therefore, while the above arguments summarize, more or less, the character of waste management policy options for the area, such options may focus on the following: -towards the development of an environmental policy with a longrange time horizon for a complex spatial and organizational system such as the Thriassion Plain; -and the application of effective waste management schemes as a result of the above action. Assessment of the existing water infrastructure, application of rigorous maintenance programs and the construction of the necessary infrastructure may be considered as first priority measures. Furthermore, the implementation of a holistic environmental management strategy with a long range time commitment, which will lead towards pragmatic steps in confronting the environmental problems, is more than necessary. It seems that such a strategy should focus on the development of a holistic program of waste management, in an area wide application of pollution control measures and enforcement standards, and in the delineation and implementation of policy actions in an orderly, coherent and timely fashion.

\section{CONCLUSIONS}

The environmental problems that Thriassion Plain faces may be grouped into four overlapping and interacting categories: (a) problems of access to environmental infrastructure and services; (b) problems of pollution from urban/industrial wastes; (c) problems of resource degradation; and (d) problems of environmental hazards. All in all, it may be pointed out that for the Thriassion Plain as well as for other regions around the world facing similar problems, the needed actions to confront such problems should be a combination of known technological principles for the wastewater system and treatment plant design, and the solid waste removal, with socially and economically acceptable management solutions to resources overexploitation, waste generated by expanding urban agglomerations, intense industrialization and consumptive lifestyles. On top of this, WFD imposes even more stringent constraints regarding pricing (cost recovery); planning; public participation and pollution control. In this context, new strategies for sustainable resources development efforts are needed because natural resources problems are becoming highly complex and globalized. It may be pointed out that the traditional spatial environmental view has been imploded and project boundaries and their impacts and consequences - are becoming much more diffuse. Hence, an environmental approach is needed that should include drastic measures of ecological rehabilitation, innovative institutional mechanisms, and a balance between autonomy and cooperation. Such integrated approaches should incorporate environmental monitoring and information by expanding the factual basis of holistic urban/industrial water management models. In addition, they should also be accompanied by a framework for negotiations that stresses the importance of comprehensive institutional formats and the clarity in local and national decision making processes. Thus, based on the above it should also be applied for Thriassion Plain, what many local and national organizations, as well as international bodies require in similar cases namely the needed research on: financing schemes (especially costrecovery and privatization); improved management (in terms of competent administration, networking, coordination, participatory and anticipatory emphasis, etc.); appropriate use of technical advances (in the form of technological innovations, rehabilitation and conservation); and, institutional streamlining (with area wide application of pollution control measures and enforcement standards, mobilization of socio-cultural resources, promotion of sustainable development ethos, and citizen empowerment). The last indicates also that there should be a fundamental shift from a prevailing crisis management approach (short-range preoccupation and technological fixes) to a more anticipatory risk management that allows us to concentrate on contingency planning and reasonably foreseeable futures. Finally, in this context waste must be recognized as an integral part of the total resources' stream and of the technology that facilitates the exploitation of natural resources towards viable recovery systems. Industrial production, growing populations and higher standards of living will always give rise to greater material consumption and, in this regard, technology could perform a double role: either as a major threat to the quality of the environment; or, also, as a potential tool for the solution of environmental problems. 


\section{REFERENCES}

Abatzoglou, G. (1987), Study of the pollution load and the pollution stage in the Gulf of Eleusis, PhD. Dissertation, National Technical University of Athens, Greece.

Antoniou, I., Anagnostou, B. and Peppas, I. (1982), Study of flood protection measures of the Thriassion Plain, Ministry of Environment, City Planning and Public Works.

ASCE/UNESCO Task Committee (1998), Sustainability Criteria for Water Resource Systems, American Society of Civil Engineers, Reston, Virginia.

Bosdogianni, A. (1997), Biodegradation of Municipal Solid Waste, PhD. Dissertation, National Technical University of Athens, Greece.

Butler, D. and Maksimovic C. (1999), Urban water management - challenges for the third millennium, Progress in Environmental Science, 1, 213-235.

Catsiki, V.A. (1991), Pollution Research and Monitoring Program in Saronikos Gulf, Ministry of Environment, City Planning and Public Works, Report IV, 1987-90.

Company of Water Supply and Wastewater of the Capital (EYDAP), (1996), Prefeasibility study of main sewerage system and stormwater system of Thriassion Plain, Athens, Greece.

Dalacu, V.P. (1998), The Multiplicity of Sources of Greek Environmental Law and the Integration of the relevant Policy, In: Proceedings of an International Conference 'Protection and Restoration of the Environment IV', Halkidiki, Macedonia, Greece, Vol. II, 815-822.

Friligos, N. (1987), Eutrophication of the Saronikos Bay. Eutrophication in the Mediterranean Sea: receiving capacity and monitoring of long-term effects, UNESCO, 1988.

Grigg, N.S. (1986), Urban Water Infrastructure: Planning, Management and Operations, John Wiley \& Sons, New York.

Karavitis, C.A. (1999a), Drought and Urban Water Supplies: the Case of Metropolitan Athens, Water Policy, 1, 505-524.

Karavitis, C.A. (1999b), Cost-Benefit Analysis for the river training works of Saint George torrent, Thriassion Plain, Company of Water Supply and Wastewater of the Capital (EYDAP), Athens, Greece.

Kounis, G. (1986), Evaluation of Vulnerability and quality of groundwater Resources in Greece, Institute of Geology and Mineral Exploration of Greece.

Ministry of Environment, City Planning and Public Works (YPEXODE), (1982), Study of flood protection measures of the Thriassion Plain, Athens, Greece.

Organization for Economic Co-operation and Development (OECD), (1983), Environmental Policies in Greece, OECD, Paris, France.

Simonovic, S.P. (1996), Decision supported systems for sustainable management of water resources: 1. General principles, Water International, 21, 223-232.

Stamatiadis (1993), City Planning of the Thriassion Plain. Research of the Industrial Areas, Prefecture of West Attica, Athens, Greece.

Uitto, J.I. and Biswas, A.K. (Eds.) (2000), Water for Urban Areas: Challenges and Perspectives, United Nations University Press, Tokyo.

UNESCO (1995), Integrated Water Resources Management in Urban and Surrounding Area, UNESCO, Paris.

United Nations Development Programme et al. (2000), World resources 2000-2001: People and Ecosystems. The Fraying Web of Life, World Resources Institute, Washington, D.C.

Vlachos, E.C. (1992), Metropolitan growth and refuse management with emphasis on Greater Athens, Report submitted to the Union of Municipalities of Attica (Greater Athens) for the EIS for solid waste disposal.

Vlachos, E.C. (1997), Importance of indicators for policy formulation: sustainability and water resources policy. In: Water 21 Workshop 'Sustainability Indicators and Criteria for Water Policy Formulation', WRc Medmenham, UK.

Vlachos, E.C. and Braga, B. (2001), The challenge of Urban Water Management, In: Frontiers in Urban Water Management: Deadlock or Hope, (Eds) C. Makcimovic and G.A. Tejada-Juibert, IWA Publishing, London, UK. 